NBER WORKING PAPER SERIES

\title{
ENVIRONMENTAL, SOCIAL, AND GOVERNANCE CRITERIA: WHY INVESTORS ARE PAYING ATTENTION
}

\author{
Ravi Jagannathan \\ Ashwin Ravikumar \\ Marco Sammon \\ Working Paper 24063 \\ http://www.nber.org/papers/w24063 \\ NATIONAL BUREAU OF ECONOMIC RESEARCH \\ 1050 Massachusetts Avenue \\ Cambridge, MA 02138 \\ November 2017
}

We thank the AQR Research Group, Craig Furfine, Kose John, David Matsa, Lukasz Pomorski, Todd Pulvino, Prateek Raj for helpful comments. We alone are responsible for any errors and omissions. The views expressed in the article are those of the authors and do not necessarily represent the views of the institutions that the authors belong to. The article has been accepted for publication in the Journal of Investment Management. The views expressed herein are those of the authors and do not necessarily reflect the views of the National Bureau of Economic Research.

NBER working papers are circulated for discussion and comment purposes. They have not been peer-reviewed or been subject to the review by the NBER Board of Directors that accompanies official NBER publications.

(C) 2017 by Ravi Jagannathan, Ashwin Ravikumar, and Marco Sammon. All rights reserved. Short sections of text, not to exceed two paragraphs, may be quoted without explicit permission provided that full credit, including $(\odot$ notice, is given to the source. 
Environmental, Social, and Governance Criteria: Why Investors are Paying Attention Ravi Jagannathan, Ashwin Ravikumar, and Marco Sammon

NBER Working Paper No. 24063

November 2017

JEL No. G0,G12,H23,Q4,Q5

\section{$\underline{\text { ABSTRACT }}$}

We find that money managers could reduce portfolio risk by incorporating Environmental, Social, and Governance (ESG) criteria into their investment process. ESG-related issues can cause sudden regulatory changes and shifts in consumer tastes, resulting in large asset price swings which leave investors limited time to react. By incorporating ESG criteria in their investment strategy, money managers can tilt their holdings towards firms which are well prepared to deal with these changes, thereby managing exposure to these rare but potentially large risks.

Ravi Jagannathan

Kellogg Graduate School of Management Northwestern University

2001 Sheridan Road

Leverone/Anderson Complex

Evanston, IL 60208-2001

and NBER

rjaganna@kellogg.northwestern.edu

Ashwin Ravikumar

Amherst College

220 South Pleasant Street

Amherst, MA 01002

ashwinra@gmail.com
Marco Sammon

Department of Financce

Kellog School

Northwestern University

2001 Sheridan Rd, Evanston, IL 60208

mcsammon@gmail.com 


\section{Introduction}

In this paper, we examine the consequences of adding Environmental, Social and Governance (ESG) criteria to money managers' investment process, focusing on the "E" part of ESG to illustrate the issues and mechanisms involved. The rapid growth of the global economy during the post-World War II era, especially over the past three decades, has strained the environment 11 Much of this growth can be attributed to the rise of China, which went from being the seventh-largest economy in 1997 to the second-largest economy today ${ }^{2}$, To put the potential environmental impact into perspective, China now produces as much steel in a year as the entire world did in $19803^{3}$

Cumulative environmental stress has not only made environmental crises more severe and more likely to occur, but has also changed how governments and consumers respond. Now, when a crisis occurs, it is more likely to incite sudden changes in regulation and consumer behavior, causing large swings in asset prices over a short period of time. Assessing such risks, and their impact on long-term returns, requires understanding how environmental crises, from global climate change to regional pollution, may lead to political disruptions and subsequent regulatory changes. Further, the concerns that lead to regulatory changes can contribute to the emergence of alternative technologies that pose a competitive threat to firms generating negative externalities.

If changes in regulation, technology and consumer tastes arrive quickly, investors will have limited time to react. Firms, however, are heterogeneously exposed to these risks. Even investors who only care about maximizing returns subject to risk budgets can use

\footnotetext{
${ }^{1}$ According to Olivier, Janssens-Maenhout, Muntean, and Peters (2016) global emissions of carbon dioxide increased by nearly $60 \%$ from 22.7 billion tonnes in 1990 to 36.2 billion tonnes in 2016. U.S. emissions increased marginally from 5.0 billion tonnes to 5.2 billion tonnes. In contrast, Chinese emissions increased from 2.4 billion tonnes to 10.7 billion tonnes. As Daniel, Litterman, and Wagner (2016) point out, the world has only one atmosphere with limited capacity for absorbing carbon dioxide - and it may become full.

${ }^{2}$ We chose 1997, as this was the year Hong Kong was returned to China by the United Kingdom. Chinese growth expanded rapidly post 2001, when it joined the World Trade Organization.

${ }^{3}$ Data from Statistical Yearbooks of the World Steel Association
} 
ESG criteria to identify firms which are well prepared to deal with changes in regulations and consumer preferences, as well as potential threats from new technologies.

To put our analysis into context, we start with the history of ESG criteria in investment decisions 4 Next, we provide a brief background on current environmental issues, focusing on carbon emissions, which may shape regulatory policy through emerging political movements and coalitions. We then discuss two commodities which have a large impact on the environment through their consumption and production: coal and palm oil. For coal, producers and industrial/utility users are subject to stringent environmental regulations. The unexpected election of Donald Trump led stock market investors to expect significant deregulation of the coal industry, and coal firms' shares rose sharply. For palm oil, which is primarily used to produce consumer goods, we find that voluntary commitments, presumably due to fear of consumer action, have altered the industry and regulatory changes may be on the horizon.

The coal and palm oil examples underscore the importance of considering regulatory risks that arise from ESG issues, particularly environmental concerns. The specific indicators that investors use to make decisions about environmental risks are, however, beyond the scope of this paper.5 While there are ongoing debates about these measures' limitations, our evidence from the coal sector suggests that environmental regulations can lead to sudden large changes in stock prices within a short period of time. Further, the palm oil example illustrates the mechanism through which social preferences for public goods/bads may influence firms and investors' behavior. Investors may reduce portfolio risks by considering how these regulatory risks are reflected in their investment decisions - whether through new or existing ESG indicators.

\footnotetext{
${ }^{4}$ As Garvey, Kazdin, LaFond, Nash, and Safa (2017) observe, firms may disclose more ESG policies when they are more exposed to controversies. An implication is that a tilting portfolio weights towards firms that disclose more may not necessarily lead to lower exposure to ESG related risks.

${ }^{5}$ For example, see Responsible Investment 2016, Government Pension Fund Global, Norges Bank Investment Management. Social and political risks - components of the S part of ESG - are getting increased attention in the academic finance literature as well: see Pástor and Veronesi (2013) and Chen, Lu, and Yang (2017).
} 


\section{The Use of ESG Criteria in Asset Management}

Assets under management of professional investors whose strategies mention Environmental, Social and Governance (ESG) criteria has grown from $\$ 13.3$ trillion in 2012 to $\$ 22.9$ trillion in 2016 6 This represents $52.6 \%$ of the total managed assets in Europe, $21.6 \%$ in USA, $37.8 \%$ in Canada, $50.6 \%$ in Australia/New Zealand, and $0.8 \%$ in Asia.

Although the principal fiduciary responsibility of institutional investors and money managers is to maximize returns, the call for considering ESG criteria while making investment decisions is not new. For example, Powers and Gunnemann (1969) "called on universities and other nonprofit institutions to consider the social consequences of corporate activities from which these institutions derive an endowment return." 77 In 1972 Yale established its advisory committee on investor responsibility as suggested in Simon, Powers, and Gunnemann (1972). However, the attention to environmental, social, and governance issues in investment decisions among professional money managers has only become widespread since the launch of the Principles for Responsible investment in 2006 by the United Nations 8

The following factors have contributed to increased investor attention to ESG criteria. First, firms may produce socially undesirable public bads, even when operating within the laws of the land, as regulation may take time to catch up with social concerns. For example, it took time for the public to realize that many cigarette advertisements were targeted at increasing addiction among the youth, and to enact legislation to regulate these advertisement: 9

In response to these negative externalities, local protests and resistance, alongside global media shaming, can harm firms' images and hurt their profits - more easily now due to the increased use of social media by the general public ${ }^{10}$ - increasing the risks

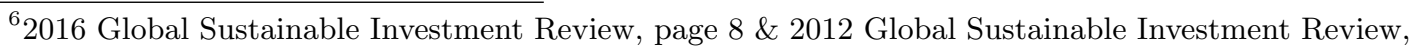
pages 9-10
'Yale Advisory Committee on Investment Responsibility: Committee History and Mission
${ }^{8}$ https://www.unpri.org/
${ }^{9}$ See the appendix for a discussion of the tobacco industry and regulation.
${ }^{10}$ On 25 April 2017, a CNBC news article mentioned that scandals may have knocked the valuation 
to investors in those firms. ESG criteria may be useful in identifying firms that are inattentive to these issues, and whose returns will be compromised when the changes come 11

Second, stocks are long lived assets, as most of the value is from cash flows that occur in the distant future. For example, from 1926-2015, less than $30 \%$ of the present value of the average 10-year investment in the S\&P 500 index came from cash dividends received during the ten years following the investment (see Figure 1). The majority of the present value came from capital gains realized at the end of the ten year period, which in turn depended on investors' expectations about what will happen over the years that followed 12

Such long horizon cash flows are difficult to forecast and can be affected by future changes in regulations and socially acceptable business practices. It is not surprising that active portfolio managers, who rely on fundamental analysis and take concentrated positions, tend to invest in well managed firms in good businesses: These firms are better positioned to adapt to changing regulatory conditions and consumer tastes. Further, there is growing evidence that all else being equal, the returns on stocks of well governed, socially responsible firms may contribute less to portfolio risk. 13

Finally, many individual investors have ethical considerations about investments that are somewhat blind to fiduciary responsibilities 14 . Easier access to information has allowed more people to become informed on these issues, and put pressure on money of Uber from $\$ 60$ billion to $\$ 50$ billion. The article mentioned, "Uber has suffered a litany of negative headlines that would have arguably dinged a publicly traded company...."

${ }^{11}$ See Meyer and Kirby (2010) for an excellent discussion of the challenges facing corporate leaders in an "Age of Transparency"

${ }^{12}$ Dividends are not the only method firms use for returning cash to investors. For every dollar of cash dividend paid, firms paid out $\$ 0.40$ through repurchase of shares net of issuances between 19902002 and $\$ 0.95$ during 2003-2015. We considered the case of an investor who did not participate in repurchases/issuances.

$\sqrt[13]{\text { Frazzini, Kabiller, and Pedersen }(2013)}$

${ }^{14}$ Consistent with the views of such investors, Hart and Zingales (2017) argue that maximizing shareholder value following the advice of Friedman (1970) is not necessarily the same as maximizing shareholder welfare, and advocate voting by shareholders on corporate policies. 
Figure 1: Consider investing $\$ 1$ in the $\mathrm{S} \& \mathrm{P} 500$ index in 10-year rolling, overlapping windows from 1926-2016. Bars 1-9 represent the share of the total net present value of the investment, paid as dividends on that year after the initial investment. Bar 10 represents the net present value of dividends paid that year, plus the terminal value of the portfolio. Dividends are not reinvested. Present value is calculated with respect to the internal rate of return over the same 10-year period. Data is from Robert Shiller's Website.

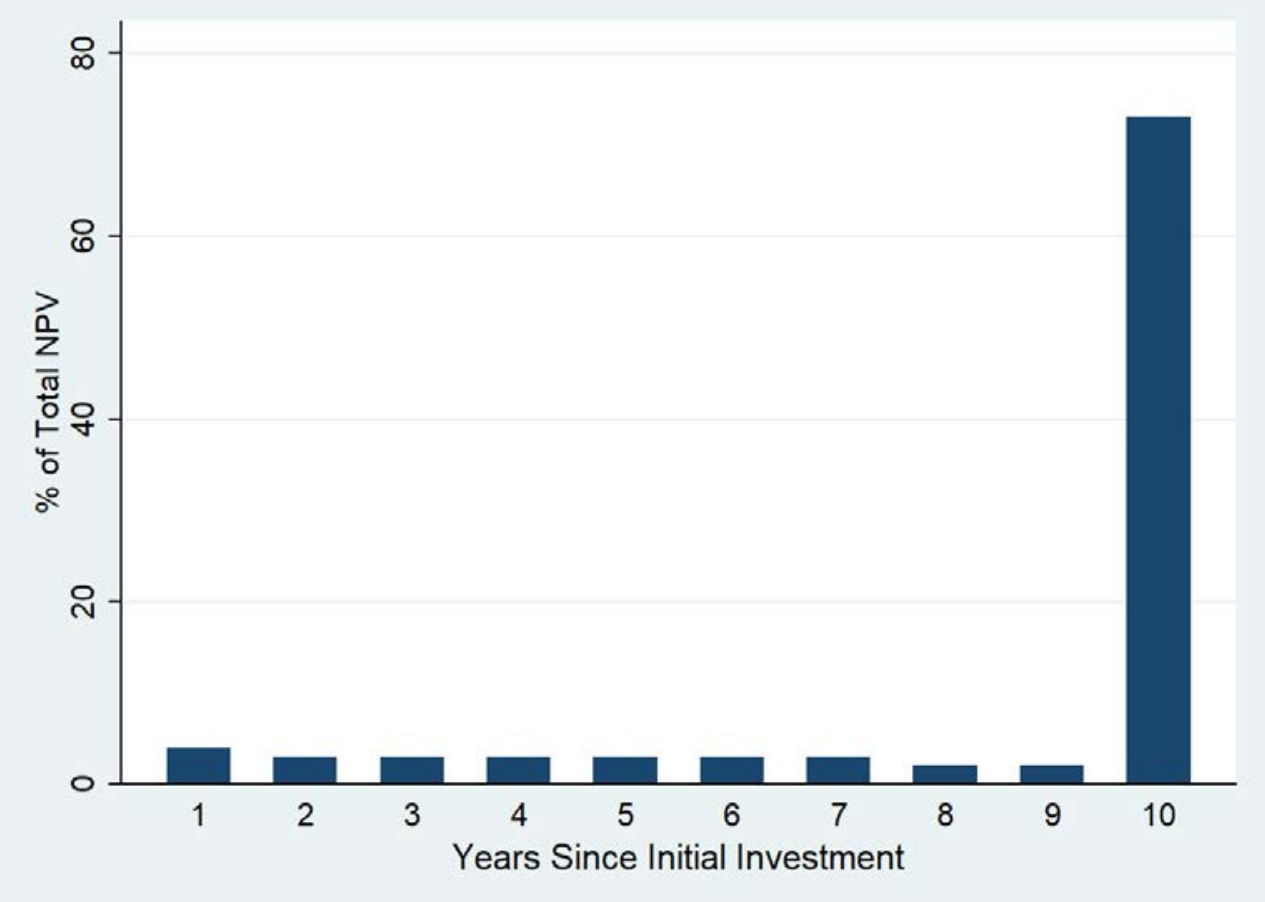


managers and firms to reduce negative externalities. Increasingly, investors are demanding total divestment from fossil fuel interests 15

\section{Environmental Issues}

\subsection{Carbon Emissions}

There is a consensus among scientist: 16 that excessive carbon emissions are a concern to society because they contribute to global warming. Climate change can threaten human health, well-being, and economic productivity 17 as well as the world's biodiversity and natural ecosystems ${ }^{18}$ Bansal, Ochoa, and Kiku (2016) and Daniel, Litterman, and Wagner (2016) argue that there is a strong case for acting soon to reduce carbon emissions. These threats are also increasingly recognized by the American and global public 19

As a result, curbing carbon emissions is becoming a political and policy priority in international spaces such as the United Nations Framework Convention on Climate Change Conference of Parties. At the Paris climate conference in December 2015, 195 countries adopted a new and unprecedented international climate deal $[20$ In the agreement, countries made specific commitments to curb emissions ${ }^{21}$ Further changes were made at the sub-national level, where some jurisdictions like California are taking additional steps to limit emissions from the private sector ${ }^{22}$

\footnotetext{
${ }^{15}$ The 2016 annual report on responsible investment of the Government Pension Fund of Norway mentions risk based divestment from 23 companies in 2016 of which three were in the oil sands sector and one in the coal fired power generation sector.

${ }^{16}$ Pachauri, Allen, Barros, Broome, Cramer, Christ, Church, et al. (2014)

17 Knox, Hess, Daccache, and Wheeler (2012)

${ }^{18}$ Bellard, Bertelsmeier, Leadley, Thuiller, and Courchamp (2012).

19 Saad and Jones (2016)

${ }^{20}$ http://ec.europa.eu/clima/policies/international/negotiations/paris/index_en.htm

${ }^{21}$ There are no penalties for noncompliance, except loss of reputation.

${ }^{22}$ http://www.arb.ca.gov/cc/ab32/ab32.htm
} 


\subsection{Carbon Regulation: Present and Future}

Although many view the Paris Agreement of 2015 as a milestone achievement for coordinated international climate change mitigation policy, the agreement has had limited practical effects ${ }^{23}$ The broad commitment of limiting warming to 2 degrees Celsius was non-binding, and countries were left to determine their own contributions to the international climate change mitigation campaign (so-called Nationally Determined Contributions, or NDCs).

There are divergent views regarding the importance of the Paris agreement for investment managers. Some institutional investors and fund managers believe that international climate policy is non-threatening to profits, assuring their investors that existing policies will not generate stranded assets or compromised revenue streams.

Others take the view that while international climate policy has yet to threaten firm profitability, impending regulations will impair firms' cash flows. Environmental regulations surrounding pollution have been bolstered by the political energy of the climate movement, both in the United States and elsewhere. For example, California has passed stricter emissions regulations, supported by a broad political coalition for environmental health and justice ${ }^{25}$ These types of regulations are likely to emerge in other sub-national jurisdictions in the United States, even as the federal government seeks to roll back environmental regulations.

\subsection{Implications for Firms and Investors}

While carbon emissions caps have yet to seriously alter firms' operations, it is possible that growing emissions could cause permanent and irreversible environmental damage resulting in serious harm to living conditions of households around the world. This, and other factors discussed below, may motivate firms and investors to limit carbon emissions.

\footnotetext{
$23 \sqrt{\text { Nordhaus and Lovering }(2016)}$

${ }^{24}$ London (2016)

${ }^{25} \overline{\text { London }}(\overline{2016})$.
} 
First, many consumers feel an ethical obligation to shift production towards lower emissions, as the negative externalities disproportionately affect the already poor and marginalized 26 Given increased awareness of these issues, and desire by consumers for ethically produced goods, it makes sense for firms to change their business practices. Second, public concern over climate change is growing, with recent events underscoring the magnitude of the problem. For example, global temperature records are broken with greater frequency than ever befor ${ }^{27}$, and February 2016 was by far the warmest month on record, generating concern among scientists at NASA and NOAA 28 As communities around the world feel the effects of climate change, the likelihood of future policies to cap private sector emissions increases. Studies have shown that perceptions of risk motivate policy action, both at the local level and national level:29, although at the national level, many factors interact in complex ways to shape climate change mitigation policy 30 . As environmental regulations proliferate, firms and investors that explore strategies to reduce carbon emissions, and position themselves effectively to take advantage of emerging and increasingly robust carbon markets, could be more competitive and ultimately more likely to succeed.

There is also the possibility that, beyond regulation, political movements can shift markets, and even strand assets, as citizens organize to penalize firms they perceive as inattentive to their values. For example, in Boulder, Colorado, citizens voted in 2011 to authorize a municipal takeover of Xcel Energy's generating capacity and transmission infrastructure to set up a municipal utility, exercising their power of eminent domain. While at time of writing, the legal battle over the cost of this infrastructure is still ongoing, the event marked a new precedent: political movements motivated by the threat of global climate change can use the power of the State to strip private entities of their productive assets if the public does not believe that private firms are sufficiently sustain-

\footnotetext{
${ }^{26}$ Wheeler and Von Braun (2013), and Mendelsohn, Dinar, and Williams $(2006)$

${ }^{27}$ Tollefson (2016), and Pachauri, Allen, Barros, Broome, Cramer, Christ, Church, et al. (2014) .

${ }^{2}$ CBS News March 17, 2016

${ }^{29}$ Dilling, Pizzi, Berggren, Ravikumar, and Andersson (2017).

${ }^{30}$ Lachapelle and Paterson (2013).
} 
able. As the perceived impacts of climate change increase over time, public discontent may lead to more frequent and intense political action that constraints firms. Further, the likelihood that regulations these movements demand are implemented may increase. These relatively unpredictable political events challenge investors' assumptions about stable property rights, and can introduce truly stranded assets even without international climate policy.

There is some international support for this view. In the UK and Germany, policymakers have promised to shut down coal plants in the near future, with Britain aiming to be coal-free by 2025. While private firms operating coal plants have historically succeeded in demanding compensation for these shutdowns 31 it is conceivable that future payouts will be lower. Firms tied entirely to these fuel sources could lose value quickly as new policies emerge and long term contracts expire. Carbon Tracker ${ }^{32}$ calculated that if the commitments of the Paris agreement are kept, billions of dollars of assets in the coal sector will be stranded.

\section{The Case of Two Commodities}

In this section we discuss recent developments from two emblematic commodity sectors: coal and oil palm. These two sectors have strong interests in activities that come into conflict with environmental sustainability, and as such have been at the forefront of managing and anticipating regulations.

\subsection{Coal}

Both regulation and deregulation can come fast, and if unanticipated, can lead to sudden moves in asset prices. In this section, we explore the effect of the 2016 US presidential election on coal firms.

One of Donald Trump's campaign promises was to end the "war on coal." According to President Trump's twitter, "Obama's war on coal is killing American jobs, making

\footnotetext{
${ }^{31}$ http://energypost.eu/realistic-uk-governments-promise-phase-coal/

${ }^{32}$ Carbon Tracker (2013), Unburnable Carbon: Wasted Capital and Stranded Assets.
} 
us more energy dependent on our enemies \& creating a great business disadvantage." Further, his America First Energy Plan 33 discusses his commitment to "reviving America's coal industry." If Donald Trump's win was unanticipated, we would expect coal producers' stocks to rise in response, as investors expect higher profits in a deregulated environment.

Based on political betting market: $\$ 4$ and sophisticated prediction algorithms 3 Trump was an unlikely winner. Consistent with this, there was a large swing in coal stock prices on November 9, 2016, suggesting Trump's proposed regulatory changes were not already incorporated into asset prices. Table 1 shows the firm-level results.

Almost all the coal firms greatly outperformed the market, and there are reasonable explanations for the weaker performances: (1) NACCO is not a pure coal firm - for example, it also owns Hamilton Beach appliances. It was included in this list because it is still the 8th largest coal producer in the US. (2) Yanzhou Coal Mining Co Ltd is majority owned by Yankuang Group, a Chinese state-owned enterprise, with no US operations. (3) Natural Resource Partners is a diversified mining company (4) Suncoke is not a coal mining firm, but a substantial part of its revenue comes from its coal logistics business. Notably, Peabody Energy, the largest US coal producer, is omitted from this list because it declared bankruptcy in April, 2016.

Consistent with his campaign promises, Trump's administration has already rolled back regulation on coal: He signed resolutions disapproving the Stream Protection Rule under the Congressional Review Act ${ }^{36}$ He also signed an Executive Order regarding the "waters of the US" rule 37 Scott Pruitt, who is known for suing the EPA over the Clean Power Plan, was made Administrator of the Environmental Protection Agency. Further, Trump's budget plan proposes a $31 \%$ cut to the EPA's funding, which could further loosen restrictions on the coal industry.

\footnotetext{
${ }^{33}$ Available at: https://www.whitehouse.gov/america-first-energy

${ }^{34}$ As of November 8, 2016, predictwise had his chances of winning at $7 \%$, predictit at $22 \%$

35 FiveThirtyEight assigned a $29 \%$ probability to a Trump win.

${ }^{36}$ https://www.congress.gov/bill/115th-congress/house-joint-resolution/38/text

37 https://www.whitehouse.gov/the-press-office/2017/02/28/presidential-executive-order-restoring-

rule-law-federalism-and-economic
} 
Table 1: Excess returns of publicly traded coal firms on the day after the 2016 US Presidential Election. This includes all firms in CRSP data with SIC codes 1200-1299 and/or NAICS codes 212111, 212112, 213113. Excess returns are calculated using the daily risk-free rate from Ken French.

Firm 11/9/2016 Return

\begin{tabular}{cc}
\hline Westmoreland Resource Partners LP & $18.96 \%$ \\
Suncoke Energy Partners LP & $6.93 \%$ \\
CNX Coal Resources LP & $11.80 \%$ \\
Arch Coal Inc & $10.44 \%$ \\
NACCO Industries Inc & $2.79 \%$ \\
Westmoreland Coal Co & $18.59 \%$ \\
Yanzhou Coal Mining Co Ltd & $1.73 \%$ \\
CONSOL Energy Inc & $9.02 \%$ \\
Alliance Resource Partners & $17.21 \%$ \\
Hongli Clean Energy Tech Corp & $12.81 \%$ \\
Natural Resource Partners LP & $5.41 \%$ \\
Alliance Holdings GP LP & $11.42 \%$ \\
Cloud Peak Energy Inc & $13.35 \%$ \\
\hline Average Return: & $10.80 \%$ \\
Market Return: & $1.46 \%$
\end{tabular}

This list does not include every publicly traded coal-producing firm - for example, Hallador Energy (HNRG) is assigned a SIC code "9999" even though most of their revenue is from coal sales This classification is likely the result of HNRG being a holding company with one coal subsidiary, one oil and gas exploration subsidiary, and one gas exploration subsidiary 
Given all these changes, one would expect coal firms to have performed strongly since Trump took office. Table 2 shows the cumulative returns for coal firms from November 2016 - March 2017. Almost all of them underperformed the market, most by substantial amounts.

One explanation for coal's poor performance, despite a favorable regulatory environment, is that the concerns which led to earlier coal regulation, also provided the necessary incentives for developing more environmentally friendly alternatives. It is clear now that regulation alone was not to blame for the coal industry's general decline over the past several years. In 2015, Goldman Sachs was already calling peak coal. According to Bloomberg, coal is being out-competed on price by natural gas, which has expanded with the development of hydraulic fracturing and horizontal drilling 38 . Finally, countries like China are shutting down coal-fired electricity plants in response to the continued smog and toxic soil crises, affecting global demand for coal. This latter point underscores that even if some policies stand to deregulate environmentally damaging sectors in the short term, the longer term global trend is toward increased regulation over time.

For coal, Trump's election led to expectations of deregulation. Similarly large swings can occur in response to expectations of increased regulation. For example, more stringent health care regulation was expected following Bill Clinton's election as US President on November 3, 1991. Consistent with this, pharmaceutical stocks declined sharply from October 30, 1992 to February 26, 1993: An equally weighted portfolio of Bristol Myers Squibb, Pfizer, Merck \& Co, and Eli Lilly \& Co lost $15.2 \%$ while the S\&P 500 index gained $5.35 \%$.

Even when governments roll back sector-specific regulations, markets may not respond if there are broader trends that make those sectors risky. Coal's performance after Trump's election suggests that investors may reduce portfolio risk by considering the long-term, systemic effects of environmental regulation.

\footnotetext{
${ }^{38}$ Even with deregulation, the lost coal mining jobs may not return. To reduce costs and increase safety, coal mines have increasingly switched to self-driving trucks and drills
} 
Table 2: Cumulative excess returns of publicly traded coal firms from November 2016 - March 2017. This includes all firms in CRSP data with SIC codes 1200-1299 and/or NAICS codes 212111, 212112, 213113. Excess returns are calculated using the monthly risk-free rate from Ken French. Yanzhou Coal Mining Co Ltd went off exchange in February 17, 2017, so the return is calculated using the last available price.

$$
11 / 16-3 / 17
$$

Firm

Cumulative Return

\begin{tabular}{cc}
\hline Westmoreland Resource Partners LP & $-21.31 \%$ \\
Suncoke Energy Partners LP & $-22.47 \%$ \\
CNX Coal Resources LP & $-10.55 \%$ \\
Arch Coal Inc & $-11.65 \%$ \\
NACCO Industries Inc & $-26.53 \%$ \\
Westmoreland Coal Co & $-16.17 \%$ \\
Yanzhou Coal Mining Co Ltd & $15.00 \%$ \\
Consol Energy Inc & $-18.46 \%$ \\
Alliance Resource Partners & $-8.65 \%$ \\
Hongli Clean Energy Tech Corp & $-50.13 \%$ \\
Natural Resource Partners LP & $9.21 \%$ \\
Alliance Holdings GP LP & $-5.28 \%$ \\
Cloud Peak Energy Inc & $-20.21 \%$ \\
\hline Average & $-14.40 \%$ \\
Market over Same Period & $12.12 \%$
\end{tabular}




\subsection{Palm Oil}

The unpredictable regulatory changes that climate crises might provoke can increase risks for investors and firms. Even without impending regulations, many private firms voluntarily reduced emissions and improved environmental practices, partly in anticipation of future regulations, and partly as a matter of corporate social responsibility in response to consumer pressure. Such firms may offer a better risk return profile to long term investors, especially active portfolio managers with concentrated holdings. To illustrate, we examine the case of palm oil in Indonesia, and its connection to deforestation and global climate change.

Globally, between $10 \%$ and $30 \%$ of carbon emissions arise from deforestation and land use change, primarily in the tropics, where dense forests and organic soils store tremendous amounts of carbon in woody biomass ${ }^{39}$ When forests are cut, and usually burned, the majority of the carbon stored there is released into the atmosphere, exacerbating global warming, and removing the forests' crucial ability to recapture carbon from atmospheric carbon dioxide. The majority of such deforestation is caused by the expansion of agriculture.

Environmental groups and social justice advocates have set their sights on oil palm (Note: "oil palm" refers to the crop, while "palm oil" refers to the oil produced from the crop) in particular for its role in driving deforestation and climate change. Palm oil is a vegetable oil with many uses, ranging from cosmetics to foods. Indonesia became the leading producer of palm oil in 2006, overtaking Malaysia, producing 34 million tons of palm oil in 2016 40 While it is difficult to know with certainty the amount of land dedicated to oil palm production, the latest estimates suggest that there are at least 8 million hectares in production 41

Despite its proliferation, oil palm plantations have caused tremendous deforestation in Indonesia, particularly in the carbon-rich peat forests of Kalimantan (Indonesian

\footnotetext{
${ }^{39}$ Tubiello, Salvatore, Ferrara, House, Federici, Rossi, Biancalani, Condor Golec, et al. (2015)

40 Indonesia-Investments, February 2, 2017

${ }^{41}$ USDA Foreign Agricultural Service, June 26, 2013
} 
Borneo) and in Sumatra. Experts estimate that millions of hectares of peatlands have been deforested in the region, and that much, but not all, of this cleared peatland is now dedicated to palm oil production 42 Cleared peatlands have resulted in roughly 500 million $\mathrm{Mg}$ of carbon dioxide emissions from the loss of above ground biomass, in addition to millions of $\mathrm{Mg}$ of annual emissions from the oxidation of subterranean peat ${ }^{43}$ Citizens, lobbyists, and experts are concerned about deforestation associated with oil palm for multiple reasons, all of which are likely to lead to more stringent regulations.

First, the emissions caused by deforestation are high, and the international community is invested in reducing deforestation in Indonesia as part of a broader climate change mitigation strategy. An important development in curtailing deforestation in Indonesia was the Norway-Indonesia memorandum of understanding signed in 201144 The Norwegian government put $\$ 1$ billion on the table as an incentive for Indonesia to halt deforestation in pristine forests, including the carbon-dense peatlands. Norway encouraged Indonesia to adopt a moratorium on new forestry and oil palm concessions as part of this arrangement, although results have been mixed 45

Second, there are regional effects associated with deforestation for oil palm trees. Peat soils in Kalimantan contain dense stores of organic matter up to 12 meters below the surface 46 Fires on the surface of the land, sometimes caused by smallholders, but increasingly near oil palm plantations, can spread underground, where they cannot be controlled. These fires have acute regional effects: smoke and haze blanketed Southeast Asia in 2015 and 2016, halting air traffic and stalling economic activity 47 Regional governments, including Singapore and Malaysia, are actively encouraging Indonesia to slow these fires, which are associated with oil palm plantations 48

\footnotetext{
$\sqrt[42]{\text { Edwards, Koh, and Laurance }(2012)}$

${ }^{43}$ ibid

${ }^{44}$ ibid

${ }^{45} \mathrm{ibid}$

${ }^{46}$ Warren, Hergoualc'h, Kauffman, Murdiyarso, and Kolka (2017)

47 Krol, Nechita, Van Leeuwen, Basu, Coheur, and Clerbaux (2016)

${ }^{48} \overline{\text { Tacconi }}(\overline{2016})$
} 
Figure 2: Reproduced with permission from the Global Forest Watch and the Global Fire Emissions Database. See the World Resources Institute website for more information.
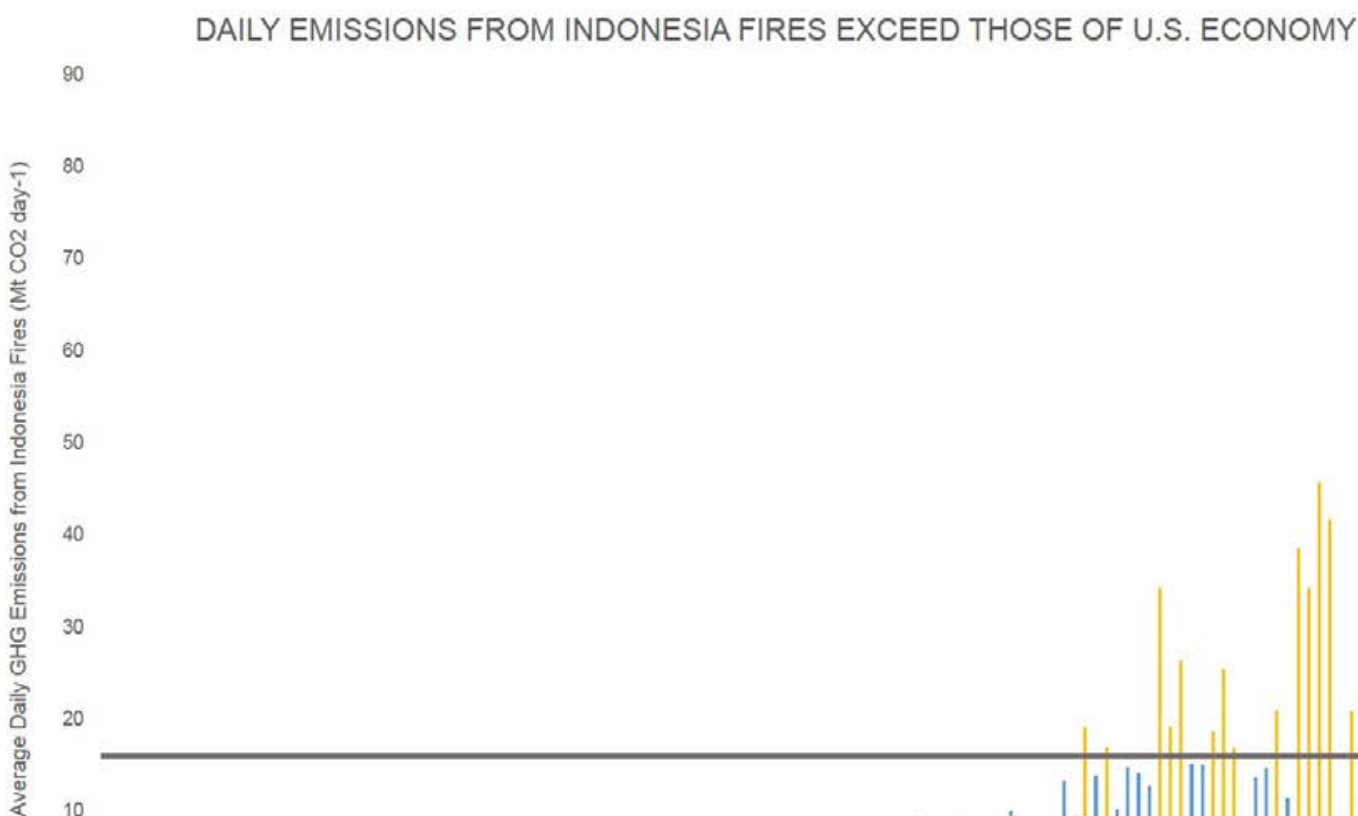

70

60

40

30

20

10

6/1/2015

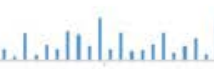
$7 / 1 / 2015$

9/1/2015

$10 / 1 / 2015$

Average Daily Emissions Below U.S. Daily Emissions (Indonesia Fires)

- Average Daily Emissions Above U.S. Daily Emissions (Indonesia Fires)

SOURCE: GLOBAL FIRE EMISSIONS DATABASE and CAIT

WORLD RESOURCES INSTITUTE

According to data from the World Fire Emission Database of the World Resources

Institute, Indonesian fires generated emissions during September and October 2015 that exceeded the average daily emission from all US economic activity (see Figure 2).

As the Indonesian government has struggled to address unchecked oil palm proliferation for a variety of reasons ${ }^{49}$ the private sector has taken matters into its own hands. Companies like Unilever, Nestle, and McDonald's have committed to eliminating deforestation from their commodity chains, and pledged to cease buying palm oil from 49 Myers, Larson, and Ravikumar $\sqrt{2016})$ 
producers who cause deforestation. These firms buy a significant share of the world's palm oil - for example, Unilever alone buys $3 \%$ of global production 50 Unilever responded to these issues, pledging to eliminate net deforestation from all of its value chains, including oil palm, by $2020^{51}$.

While the success of Unilever's initiatives in reducing deforestation is not yet known, their commitment - and their continued success as a firm - showcases the potential synergies between sustainable production, long run risks, and profitability 52

Corporate pledges have teeth. According to a recent report, the unwillingness of major global palm oil buyers to purchase unsustainable palm oil, based on standards set by the Roundtable on Sustainable Palm Oil (RSPO), has stranded 6.1 million hectares, or 10 million football fields, of oil palm assets in Indonesia.53, Not only are foreign governments like Norway and firms like Unilever urging action, but growing coalitions within Indonesia are pressing for regulatory changes. Such changes are required as India, China, Pakistan, Egypt, Bangladesh and Myanmar together account for nearly half of the palm oil imports, and consumers in those countries are much more sensitive to price than environmental issues. The coalescence of these local and global movements has already had unprecedented impacts on land use policy in Indonesia, and will likely have similar effects across the global South.

The indigenous peoples' (adat) movement has long lobbied for customary lands held by them to be recognized formally by the government. While Indonesia's constitution

\footnotetext{
$5 0 \longdiv { \text { Alonso-Fradejas, Liu, Salerno, and Xu } } ( 2 0 1 6 )$

51 https://www.unilever.com/sustainable-living/transformational-change/eliminating-deforestation/

52 Unilever CEO Paul Polman discussed these at the UN COP 20 in Lima in 2014. As of 2017, 36\%

of its palm oil is certified by Roundtable on Sustainable Palm Oil, and Unilever has stated its refusal to buy additional palm oil from producers who are in violation of its Sustainable Living Plan, even though it may cost more. See Levin, Ng, Fortes, Garcia, Lacey, and Grubba (2012) for a rigorous assessment of the costs and benefits of sustainable palm oil production. This includes producers who generate net deforestation, grow oil palm on peatlands, or that the company deems to exploit local people. See Morel, Friedman, Tulloch, and Caldecott (2016)

rs https://seekingalpha.com/article/4046193-indonesian-palm-oils-stranded-assets-10-million-footballfields
} 
ostensibly recognizes indigenous rights, there had been no policies enacted to formally title communities on the basis of customary usage until 2012. The Constitutional Court of Indonesia, likely responding to growing indigenous discontent alongside international pressure, ruled that the government must recognize customary lands. A side effect of this policy was to move more land off the table for environmentally destructive oil palm production 54

As mounting evidence underscores the gravity of the global climate crisis, a growing number of firms are acting proactively to manage risks from regulatory exposure. This is not limited to firms in the energy sector. From the technology sector, to clothing, to agriculture, firms are making voluntary commitments to sustainable and socially responsible practices in their supply chains. Examples include: Apple, which recently reported that all current products' supply chains have participated in an independent third-party conflict minerals audit program $[55$ Patagonia, which responded to pressure from consumers by pledging to eliminate toxic materials from its inventory following a damaging report from Greenpeace; and large firms like Tesco and H\&M which have committed to $100 \%$ sustainable cotton by 202556 .

\section{Conclusion}

While the principal fiduciary responsibility of professional money managers is to maximize returns, they may reduce portfolio risks by considering their clients' Environmental, Social, and Governance (ESG) concerns. While it may appear that ESG considerations come at the expense of higher returns, we argue otherwise. Even those who care only about risks and returns may reduce exposure to systematic risks by incorporating ESG criteria into their investment process.

Given their increased severity and frequency, environmental crises are more likely to cause sudden changes in regulations, technology and consumer tastes. These rapid

\footnotetext{
${ }^{54}$ Myers, Larson, and Ravikumar $(2016)$

${ }^{55}$ Form SD filed on 5/5/2017 filed with the SEC.

56 Thirteen firms set 2025 deadline to source 100 percent sustainable cotton
} 
changes can cause large swings in asset prices, leaving investors with limited ability to react. By incorporating ESG criteria in their investment strategy, portfolio managers can proactively select firms which are well prepared to deal with these changes, and protect themselves from downside risk.

It is difficult to measure whether information available in ESG criteria are already priced in by the market, as reliable firm-level data on ESG measures over sufficiently long periods of time are not publicly available. Investors who believe in informationally efficient markets focus on allocation across asset classes to construct well diversified portfolios. ESG-related risks, however, can be rare, large, and non-diversifiable 57 ESG criteria may help such investors assess exposure to these risks better than a purely statistical model which relies on historical data. Investors who believe that the market can be inefficent at times, and take concentrated positions to reflect their view 58 may also reduce risks by considering ESG criteria.

Incorporating ESG criteria into quantitative investment models requires additional work and creation of reporting standards 59 Research has already started in this direction 60 Turning a qualitative procedure, such as evaluating risk of environmental regulation, into a quantitative procedure, however, will take time: Warren Buffett was investing for over 50 years before researchers have come up with a way to replicate his strategy using quantitative methods 61

\footnotetext{
${ }^{57}$ See Hamilton $(1996)$ for a discussion of the relation between oil prices and recessions.

${ }^{58}$ See Lakonishok, Shleifer, and Vishny (1994), Shleifer $(2000)$, and Piotroski (2000).

${ }^{59}$ The Sustainability Accounting Standards Board is working towards creating reporting standards. Measurement issues, however, are still first-order. For example, over $70 \%$ of financial firms that went bankrupt in the 07-08 crisis, including those who were making many "low-doc" loans, had above average governance scores according to MSCI. Further, as supply chains continue to move overseas, it may become more difficult to measure a firm's true environmental impact.

${ }^{60}$ For example, Dunn, Fitzgibbons, and Pomorski (2017) find that ESG criteria have predictive power for future realized risk, even conditioning on a sophisticated statistical model and well-known risk factors. ${ }^{61}$ Frazzini, Kabiller, and Pedersen (2013) find that Berkshire Hathaway's alpha with respect to a 4factor model is insignificant after adding low risk and high quality factors from Frazzini and Pedersen (2014) and Asness, Frazzini, and Pedersen (2014).
} 


\section{References}

Alonso-Fradejas, A., J. Liu, T. Salerno, and Y. Xu (2016): "Inquiring into the political economy of oil palm as a global flex crop," The Journal of Peasant Studies, 43(1), 141-165.

Asness, C. S., A. Frazzini, and L. H. Pedersen (2014): "Quality minus junk," .

Bansal, R., M. OchoA, And D. KiKu (2016): "Climate change and growth risks," Discussion paper, National Bureau of Economic Research.

Bellard, C., C. Bertelsmeier, P. Leadley, W. Thulller, and F. Courchamp (2012): "Impacts of climate change on the future of biodiversity," Ecology letters, 15(4), 365-377.

Chen, Z., A. Y. Lu, and Z. Yang (2017): "Growing Pains: International Instability and Equity Market Returns," Financial Management, 46(1), 59-87.

Daniel, K. D., R. B. Litterman, and G. Wagner (2016): "Applying asset pricing theory to calibrate the price of climate risk," Discussion paper, National Bureau of Economic Research.

Dilling, L., E. Pizzi, J. Berggren, A. Ravikumar, and K. Andersson (2017): "Drivers of adaptation: Responses to weather-and climate-related hazards in 60 local governments in the Intermountain Western US," Environment and Planning A, p. $0308518 X 16688686$.

Dunn, J., S. Fitzgibbons, And L. Pomorski (2017): "Assessing Risk Through Environmental, Social and Governance Exposures," Journal of Investment Management.

Edwards, D. P., L. P. Koh, and W. F. Laurance (2012): "Indonesia's REDD+ pact: Saving imperilled forests or business as usual?," Biological Conservation, 151(1), 41-44. 
Frazzini, A., D. Kabiller, and L. H. Pedersen (2013): "Buffett's alpha," Discussion paper, National Bureau of Economic Research.

Frazzini, A., And L. H. Pedersen (2014): "Betting against beta," Journal of Financial Economics, 111(1), 1-25.

Friedman, M. (1970): "The Social Responsibility of Business is to Increase Its Profits," New York Times, September.

Garvey, G. T., J. Kazdin, R. LaFond, J. Nash, and H. Safa (2017): "A Pitfall in Ethical Investing: ESG Disclosures Reflect Vulnerabilities, not Virtues," Journal of Investment Management, 15(2), 51-64.

Hamilton, J. D. (1996): "This is what happened to the oil price-macroeconomy relationship," Journal of Monetary Economics, 38(2), 215-220.

Hart, O., And L. Zingales (2017): "Companies Should Maximize Shareholder Welfare Not Market Value," Forthcoming Journal of Law, Finance, and Accounting.

Knox, J., T. Hess, A. Daccache, and T. Wheeler (2012): "Climate change impacts on crop productivity in Africa and South Asia," Environmental Research Letters, $7(3), 034032$.

Krol, M., N. Nechita, T. Van Leeuwen, S. Basu, P.-F. Coheur, and C. ClerBAUX (2016): "Carbon Emissions from the 2015 Indonesian fires," in Living Planet Symposium 2016.

Lachapelle, E., and M. Paterson (2013): "Drivers of national climate policy," Climate policy, 13(5), 547-571.

Lakonishok, J., A. Shleifer, and R. W. Vishny (1994): "Contrarian investment, extrapolation, and risk," The journal of finance, 49(5), 1541-1578.

Levin, J., G. NG, D. Fortes, S. Garcia, S. Lacey, and D. Grubba (2012): "Profitability and sustainability in palm oil production," Analysis of Incremental Financial Costs and Benefits of RSPO Compliance. WWF-US, FMO, CDC. 
London, J. K. (2016): "Environmental Justice and Regional Political Ecology converge in the other California," Journal of Political Ecology, 23(1), 147-158.

Mendelsohn, R., A. Dinar, and L. Williams (2006): "The distributional impact of climate change on rich and poor countries," Environment and Development Economics, 11(2), 159-178.

Merton, R. C. (1980): "On estimating the expected return on the market: An exploratory investigation," Journal of financial economics, 8(4), 323-361.

Meyer, C., And J. Kirby (2010): "Leadership in the Age of Transparency," Harvard Business Review, 88(4), 38-46.

Morel, A., R. Friedman, D. J. Tulloch, and B. Caldecott (2016): "Stranded Assets in Palm Oil Production: A Case Study of Indonesia," .

Myers, R., A. LARson, And A. Ravikumar (2016): “Analyzing multilevel governance in Indonesia: lessons for REDD+ through land use change and benefit sharing in Central and West Kalimantan, Indonesia," CIFOR Occasional Paper.

Nordhaus, T., and J. Lovering (2016): "Does Climate Policy Matter?-Evaluating the Efficacy of Emissions Caps and Targets Around The World," The Breakthrough Institute, 28.

Olivier, J. G., G. Janssens-Maenhout, M. Muntean, and J. A. Peters (2016): "Trends in Global CO2 Emissions 2016 Report," SSRN Working Paper.

Pachauri, R. K., M. R. Allen, V. R. Barros, J. Broome, W. Cramer, R. Christ, J. A. Church, ET AL. (2014): Climate change 2014: synthesis report. Contribution of Working Groups I, II and III to the fifth assessment report of the Intergovernmental Panel on Climate Change. IPCC.

PÁstor, L., And P. Veronesi (2013): "Political uncertainty and risk premia," Journal of Financial Economics, 110(3), 520-545. 
Piotroski, J. D. (2000): "Value investing: The use of historical financial statement information to separate winners from losers," Journal of Accounting Research, pp. $1-41$.

Powers, C. W., And J. P. Gunnemann (1969): "Institutions, Investments and Integrity," The Christian Century January, 29, 144-148.

SAAD, L., And J. M. Jones (2016): "U.S. Concern About Global Warming at EightYear High," Gallup Poll, Mar 2-6.

SHLEIFER, A. (2000): Inefficient markets: An introduction to behavioural finance. OUP Oxford.

Simon, J. G., C. W. Powers, and J. P. Gunnemann (1972): "The ethical investor: Universities and corporate responsibility," .

TACCONi, L. (2016): "Preventing fires and haze in Southeast Asia," Nature Climate Change, 6(7), 640-643.

Tollefson, J. (2016): "2015 breaks heat record: Pacific Ocean warming helped to make last year the hottest in history," Nature, 529(7587), 450-451.

Tubiello, F. N., M. Salvatore, A. F. Ferrara, J. House, S. Federici, S. Rossi, R. Biancalani, R. D. Condor Golec, et Al. (2015): "The contribution of agriculture, forestry and other land use activities to global warming, 1990-2012," Global change biology, 21(7), 2655-2660.

Warren, M., K. Hergoualc'h, J. B. Kauffman, D. Murdiyarso, and R. Kolka (2017): “An appraisal of Indonesia's immense peat carbon stock using national peatland maps: uncertainties and potential losses from conversion," Carbon balance and management, 12(1), 12 .

Wheeler, T., and J. Von Braun (2013): "Climate change impacts on global food security," Science, 341(6145), 508-513. 


\section{Appendix}

\section{Tobacco and Regulation}

Although tobacco regulation increased significantly over the past 40 years, tobacco stocks have outperformed the S\&P 500 index each decade, except the 1990's (see Figure 3). Poor performance in the 90's may be due to several regulations and lawsuits: (1) 1993 laws to increase the minimum smoking age and increase enforcement of laws against selling tobacco to minors (2) FDA rule of 1996 to regulate tobacco. 62 (3) 1998 Master Settlement, as well as individual state settlements, which forced tobacco companies to make large payments in perpetuity to recover Medicaid costs. The Master Settlement also stopped certain tobacco advertisements, such as those targeted at children.

One explanation for tobacco firms' high returns after the 90's is that they earn a risk premium for exposure to future regulation/lawsuits, which would impair returns as they did in the 90's. As argued by Merton (1980), however, a long time series is required to accurately measure average returns or jump risk. As reliable ESG data does not have a long history, we leave future research to determine whether or not this type of regulation risk earns a premium in equilibrium.

\footnotetext{
${ }^{62}$ The Supreme Court overturned this in 2000, ruling that the FDA could not regulate tobacco.
} 
Figure 3: Value of $\$ 1$ invested at the start of each decade, reinvesting all dividends. The smoke industry, based on the 48 industry portfolios on Ken French's website, is all firms with SIC codes between 2100 and 2199, which includes the following Industry Groups: Cigarettes, Cigars, Chewing Tobacco/Snuff and Tobacco Stemming/Redrying. The smoke portfolio is a value-weighted average of all firms in the smoke industry. S\&P 500 returns are from CRSP. Smoke industry returns are from Ken French's website.

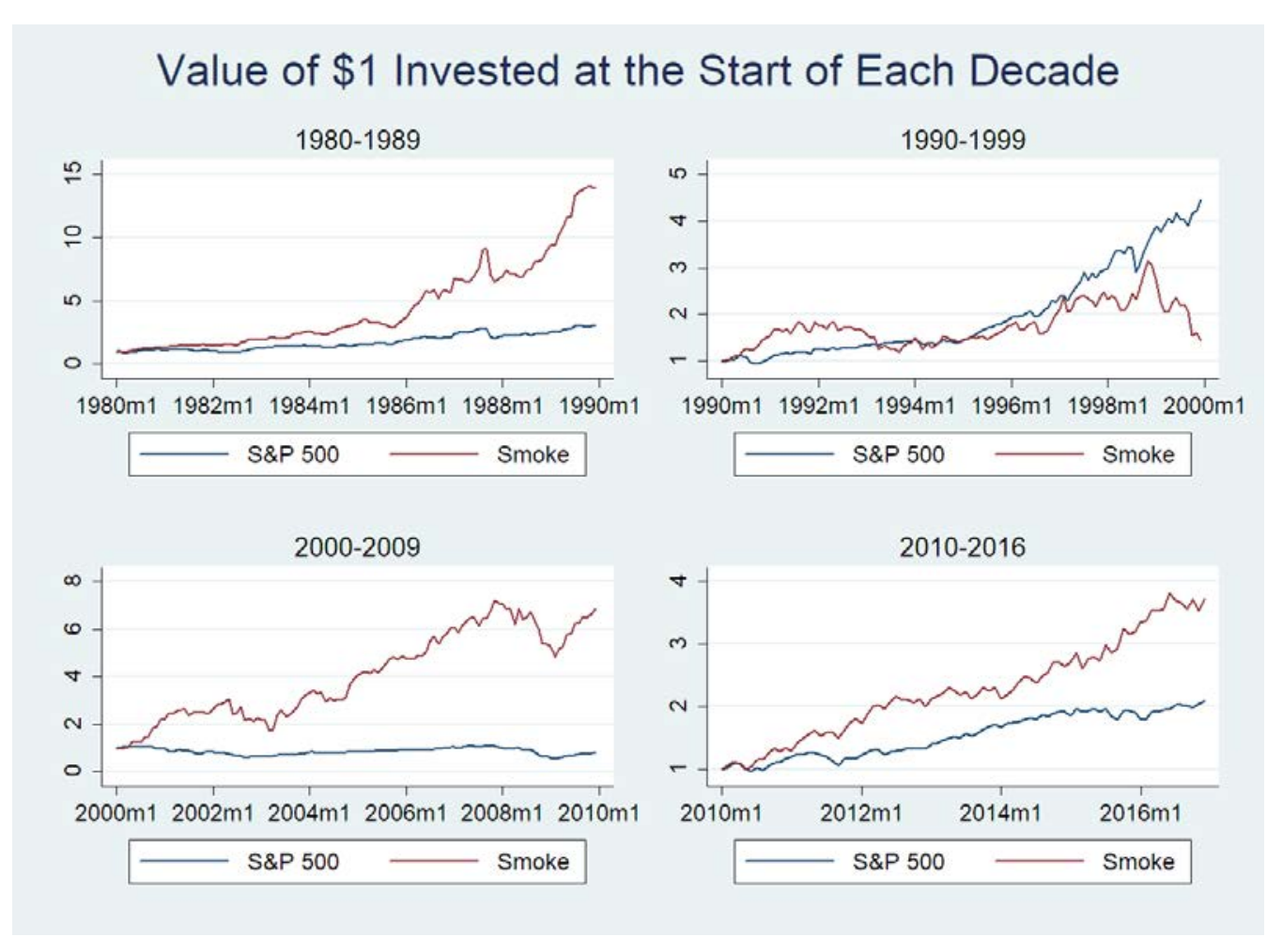

